\title{
Ornamental Vegetables: Production Tips and Varieties to Produce or Sell 1
}

\section{Dr. James L. Gibson ${ }^{2}$}

Landscapes that become battered and worn-looking as a result of the summer's heat are a gardening reality in Florida. This leads to a heightened disinterest in gardening during summer, but great anticipation for ways to enjoy the garden in fall and winter. Planting ornamental mustards and kales in the landscape is a great way to garden in the cool season. Growers should take advantage of the increasing demand for these cool season items because they are inexpensive and quick to produce (typically 4 to 6 weeks from sowing).

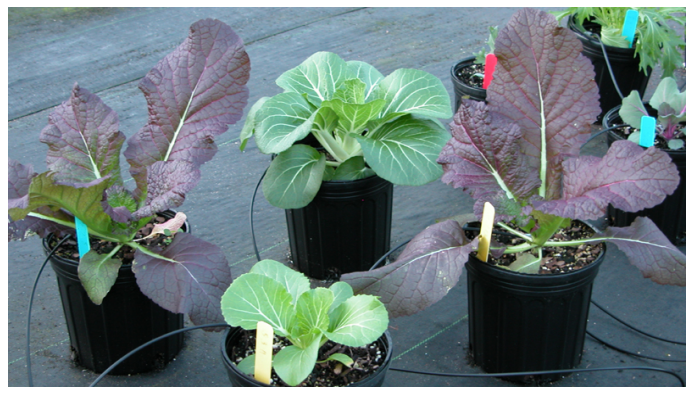

Figure 1. Gallon pot production of ornamental vegetable cultivars Red Giant and Joi Choi.

\section{Plant Trials on the Gulf Coast}

From October 23, 2003 to April 12, 2004, twenty-three ornamental vegetables were evaluated in containers or in garden soil twenty miles north of the Gulf of Mexico at the West Florida Research Education Center (WFREC) in Milton. Garden evaluation of ornamental vegetables was conducted to provide area landscapers with recommended varieties to plant during the cool season. In general for Gulf Coast landscapes, mustard cultivars should be planted in early fall to ensure an attractive display of foliage before bolting in late winter and early spring, while kale cultivars should be planted later in fall for winter and early spring interest.

Below are descriptions and cultural information for some of the best performing varieties trialed in the Milton Gardens. Listed in Table 1 are specific cultivars with their appropriate botanical classification. For detailed cultivar information, visit:

http://wfrec.ifas.ufl.edu/faculty/gibson/ ornamental_vegetables.htm.

\footnotetext{
1. This document is ENH1044, one of a series of the Environmental Horticulture Department, Florida Cooperative Extension Service, Institute of Food and Agricultural Sciences, University of Florida. Original publication date August 24, 2006. Please visit the EDIS web site at http://edis.ifas.ufl.edu. 2. Dr. James Gibson, Assistant Professor, Environmental Horticulture Department, West Florida Research and Education Center, Milton FL 32583 The use of trade names in this publication is solely for the purpose of providing specific information. UF/IFAS does not guarantee or warranty the products named, and references to them in this publication does not signify our approval to the exclusion of other products of suitable composition.
} 


\section{Hardy Kale Cultivar Descriptions}

'Red Bor' is a kale variety with extremely curled leaf margins. A tall growth habit and outstanding ability to proliferate in the cold makes 'Red Bor' an excellent performer. 'Red Bor' also "colors up" 2 to 4 weeks earlier than any of the curly ornamental kale cultivars. Planted in a mass or used just as a specimen in the garden, the purplish-red foliage of 'Red Bor' will provide any dormant shrub or perennial garden with vibrant color. 'Winterbor' is very similar to 'Red Bor' in terms of foliage characteristics and cold tolerance, but has olive green leaves.

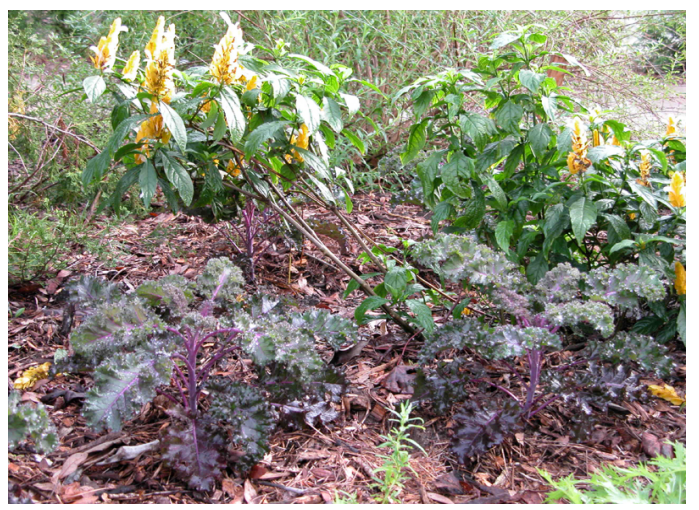

Figure 2. As colorful, tropical plants begin to feel the pinch of cool weather, ornamental vegetables like 'Red Bor' enhance the northwest Florida landscape.

\section{Mustard Cultivar Descriptions}

The 'Giant Red' mustard or 'Red Giant' has been one of the most popular ornamental vegetables used by landscapers in the Southeast. This vigorous growing plant has white midribs with bronze foliage. The plant does well in protected areas away from winter winds. As temperatures rise in the spring, the fleshy leaves expand rapidly, making the plant attractive when mixed with spring pansies and bulbs. 'Red Giant' grown in mass has a striking display, and when used as a specimen, this sprawling plant represents a focal point in the winter garden.

The potherb mustard 'Mizuna,' 'Early Mizuna' or 'Kyona' is a finely-textured plant with bright green leaves arising from a fleshy tan crown. Potherb mustard's mounded growth habit makes it an excellent plant to be used in masses or as a specimen plant. Early fall is the optimal planting time for potherb mustard due to dieback from freezing

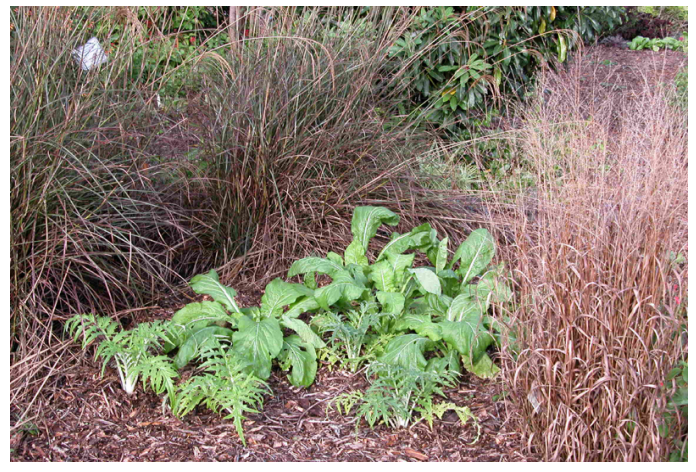

Figure 3. Ornamental vegetables with ornamental grasses.

temperatures. Three other Japanese greens that performed well include 'Komatsuna,' 'Misome,' and 'Miike Giant.'

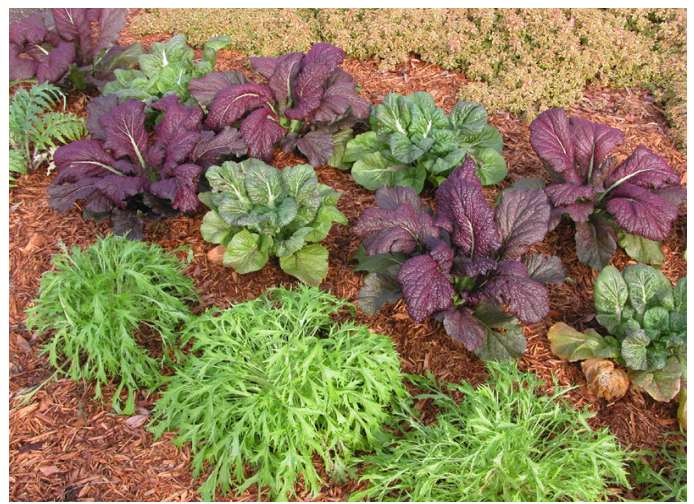

Figure 4. A mixed planting of 'Miike Giant,' 'Red Giant' and 'Early Mizuna.'

\section{Ornamental Vegetable Production}

The production of ornamental vegetables is relatively simple. Fertilize ornamental vegetables on a continual basis until sale with a soluble fertilizer (150 to $200 \mathrm{ppm} \mathrm{N}$ ) that has a high percentage (>70\%) of nitrate-nitrogen. If growers apply pesticides (plant growth regulators (PGRs), insecticides, or fungicides), then consumers need to be advised not to eat the treated plants. Also, wholesale growers need to provide retailers with a history of pesticides applied to the crop. Two foliar sprays of B-Nine at 2,500 ppm are recommended for height control of hardy kale varieties, while Sumagic $\AA$ rates between 6 and 12 ppm or B-Nine at $2500 \mathrm{ppm}$ sprayed twice or a single application at $5,000 \mathrm{ppm}$ controlled growth of ornamental mustards. 


\section{Other Vegetables}

'Flat Pak-Choi' or 'Tatsoi' makes an excellent border plant in pansy displays. 'Tatsoi' may reach 6 to 8 inches in height, and with its flat, dark green foliage, the plant in mass creates a dense mat. Because 'Tatsoi' has a low growth habit, growers should not apply plant growth regulators. If growers desire to have more pronounced white petioles, nitrogen rates of 125 to $150 \mathrm{ppm}$ are recommended. Another type of Pac Choi called 'Joi Choi' has bright white petioles with large fan-like leaves. The rapid growth rate of 'Joi Choi' allows growers to market plants 2 to 3 weeks after transplanting, thus avoiding the use of plant growth regulators.

\section{Ornamental Cabbage and Kale}

Ornamental cabbage and kale are a traditional yet profitable crop to have in a fall production program. Publications addressing cultivar selection, chemical plant growth regulation, nutrition strategies, and pinching of ornamental cabbage and kale can be found at www.ces.ncsu.edu/floriculture/crop/crop_kale.htm.

\section{Plant Growth Regulators}

Two applications of $2,500 \mathrm{mg} \mathrm{L}^{-1} \mathrm{~B}$-Nine is one option for southeastern wholesale growers interested in economical ( $\$ 0.01$ per pot) control of ornamental cabbage and kale height.

Sumagic $®$ foliar sprays between 8 and 16 ppm were effective in controlling plant growth, but cost the grower from $\$ 0.04$ to $\$ 0.07$ per pot.

\section{Nutrition}

Growers who reduce or discontinue fertilization prior to sale may increase the incidence of mineral deficiency that may occur in ornamental cabbage on the market date. Dramatic decreases in nutrient concentrations will occur at market stage if plants are subjected to clear water irrigations prior to sale. In order for wholesale growers to maximize sales, ornamental cabbage plants should be fertilized at concentrations of nitrogen at 200 to $250 \mathrm{ppm}$, so that if clear water irrigations are used at the retail outlet, nutrient reserves will be sufficient in the substrate to provide proper fertility.

\section{Pinching}

Ornamental cabbage and kale are best viewed from above or on slopes, making the attractive center colors more visible to people. But how can one create a color display of ornamental cabbage for people who view the cabbage from afar or on the same plane? Answer: You manually pinch the plants or plant multiple plugs per pot. A hard pinch to the third node ten days after planting is recommended. Triple plugging is also recommended but PGRs must be applied regularly to maintain proportion with the pot.

\section{Resources}

\section{Related EDIS Extension Publications:} Florida.

Specialty Asian Vegetable Production in South http://edis.ifas.ufl.edu/pdffiles/CV/CV13900.pdf

Guidelines for Chinese Leafy and Root Crop Vegetable Production in South Florida. http://edis.ifas.ufl.edu/pdffiles/CV/CV14000.pdf

\section{Other Resources:}

Gibson, J.L., S. Crowley, and L. Mullinax. Ornamental Vegetable Cultivar Comparison Study. University of Florida-Milton. http://wfrec.ifas.ufl.edu/faculty/gibson/ Orn_Veg_Trials/ornamental_vegetables.htm (2004).

Gibson, J.L. and B.E. Whipker. Multiple-headed Ornamental Cabbage and Kale. North Carolina State University. http://www.ces.ncsu.edu/depts/hort/floriculture/hrs/ Kale_pinching_doc.pdf (2000).

Gibson, J.L. and B.E. Whipker. Ornamental Cabbage and Kale Cultivar Trial. North Carolina State University. http://www.ces.ncsu.edu/depts/hort/floriculture/crop/ cab_kale.htm (2000).

Gibson, J.L. and B.E. Whipker. Ornamental Vegetable Cultivar Trial. North Carolina State University. http://www.ces.ncsu.edu/depts/hort/floriculture/crop/ ornveg/cultrial_2000.htm (2000). 
Gibson, J.L. and B.E. Whipker. Revising the Fertilization Strategy for Ornamental Cabbage. Horticultural Research Series No. 143. North

Carolina State University.

http://www.ces.ncsu.edu/depts/hort/floriculture/hrs/ Hrs 143.pdf (2000).

Gibson, J.L. and B.E. Whipker. Ornamental cabbage and kale growth control with B-Nine, Bonzi, and Sumagic. Horticultural Research Series No. 142. North Carolina State University. http://www.ces.ncsu.edu/depts/hort/floriculture/hrs/ Hrs142.pdf (2000).

Gibson, J.L., B.E. Whipker, R. Cloyd, and R. Jones. 1999. Success with ornamental vegetables as floricultural crops. NC State Univ. HIL 508. North Carolina State University. http://www.ces.ncsu.edu/depts/hort/floriculture/hils/ HIL508.pdf (1999).

Whipker, B.E., J. L. Gibson, R.A. Cloyd, C.R. Campbell, and R. Jones. 1998 Success with ornamental cabbage and kale. NCSU Horticultural Information Leaflet No. 507. 9 pp. North Carolina State University. http://www.ces.ncsu.edu/depts/hort/floriculture/hils/ HIL507.pdf (1998). 
Table 1. Recommended vegetable cultivars to produce and sell.

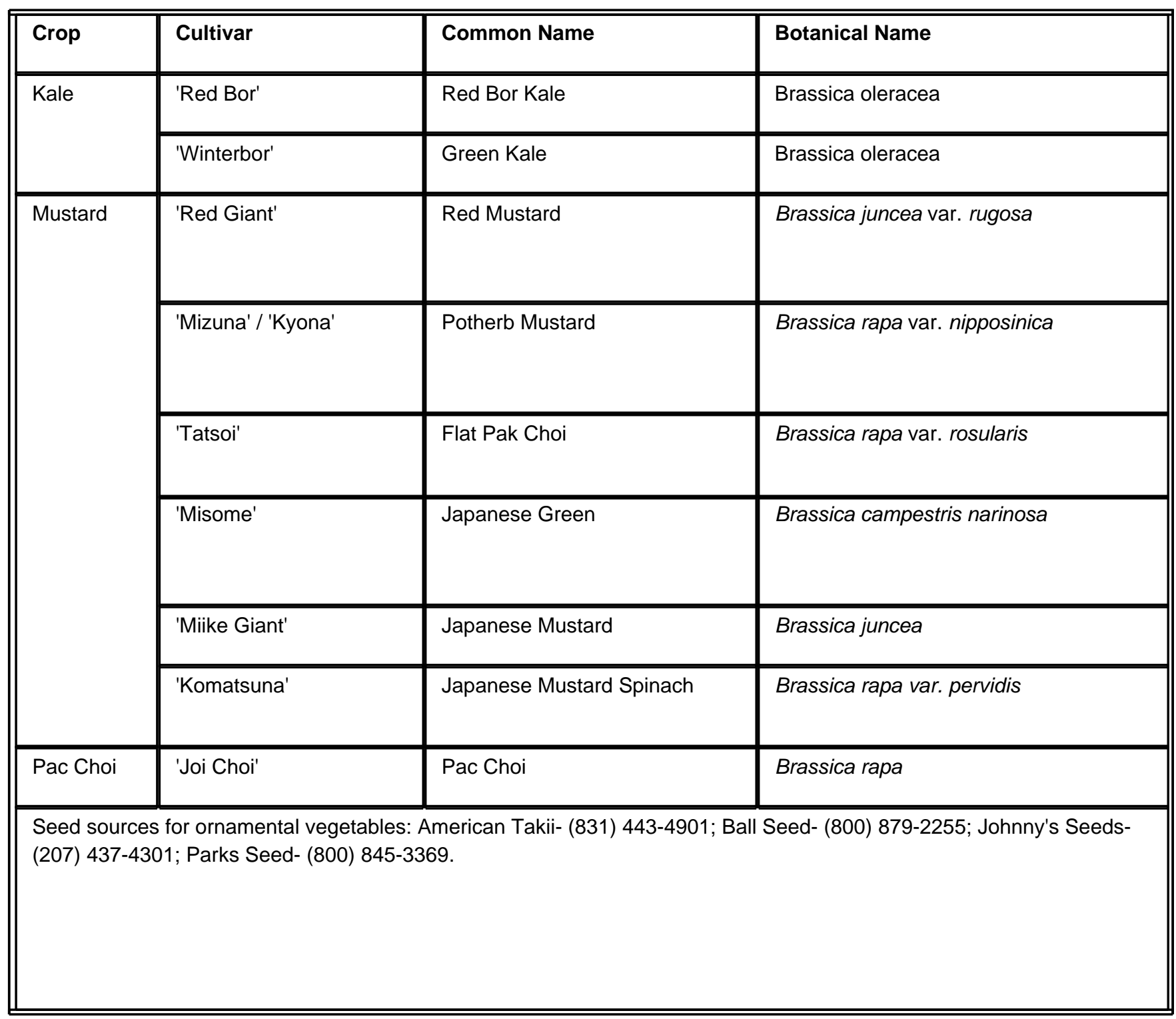

